\section{Growth and Protein Content of Apple in Response to Root and Shoot Temperature following Chilling}

\author{
Michael A. Arnold' and Eric Young ${ }^{2}$ \\ Department of Horticultural Science, North Carolina Slate University, \\ Raleigh, NC 27695- 7609
}

Additional index words. Malus $\times$ domestica, dormancy, root regeneration potential, adventitious shoots, root sucker, postharvest storage, seedling establishment

\begin{abstract}
Bare-root Malus $x$ domestica Borkh. seedlings were chilled for 0, 600, 1200 , or 1800 hours at $5 \mathrm{C}(\mathrm{CH})$. Seedlings were then placed with roots and/or shoots in all combinations of 5 and $20 \mathrm{C}$ forcing conditions (FC) for up to 21 days. Virtually no growth occurred at 5C FC. When the whole plant was forced at $20 \mathrm{C}$, all measures of root and shoot growth increased in magnitude, occurred earlier and at a faster rate with increasing $\mathrm{CH}$. Thus, roots and shoots responded similarly to chilling. When shoots or roots were subjected to $20 \mathrm{C} \mathrm{FC}$, while the other portion of the plant was at $5 \mathrm{C}$, the responses were reduced in magnitude and delayed. However, the overall growth enhancement by chilling was not negated. Root and shoot growth enhancement by chilling appeared to be increased if the other portion of the plant was actively growing also, but not dependent on it. Growth of adventitious shoots on roots (root suckers) was greatly enhanced with increasing $\mathrm{CH}$ on plants subjected to $5 \mathrm{C}$ shoot and $20 \mathrm{C}$ root FC. While total root and shoot bark protein levels on a per-seedling basis were similar, protein concentrations were lower in root bark than in shoot bark. During chilling, total protein per seedling generally increased until just before the time that chilling requirements for vegetative budbreak were satisfied. Protein degradation then began, resulting in lower protein levels through $2300 \mathrm{CH}$. Rapid protein breakdown (1200 to $1800 \mathrm{CH}$, roots; 1000 to $1800 \mathrm{CH}$, shoots) occurred at about the same time that root (1000 to $1800 \mathrm{CH})$ and shoot $(800$ to $1800 \mathrm{CH})$ growth responses to chilling were increasing. Warm FC resulted in increased protein breakdown with increased $\mathrm{CH}$ and forcing time.
\end{abstract}

Recent studies indicate that there is an increase in the magnitude of root regeneration in Malus spp. following exposure to chilling temperatures (Arnold. 1990; Arnold and Young, 1990; Young and Werner, 1984, 1985b). While Young and Werner (1985b) found some differences among seedling $M$. $\mathrm{x}$ domestica rootstocks and clonal apple rootstocks in their responses to chilling, all had similar overall enhancements of root growth in response to chilling. Similar enhancements in root regeneration potential (RRP) have been reported in other species

Received for publication 14 Dec. 1989. Paper no. 12500 of the Journal Series of the North Carolina Agricultural Research Service, Raleigh, NC 276957601. This study will be included as part of a dissertation to be written in partial fulfillment of the requirements for the $\mathrm{PhD}$ degree by M.A.A. The USC of trade names in this publication does not imply endorsement by the NCARS of the products named, nor criticism of similar ones not mentioned. The cost of publishing this paper was defrayed in part by the payment of page charges. Under postal regulations, this paper therefore must be hereby marked advertisement solely to indicate this fact.

${ }^{1}$ Graduate Research Assistant. Present address: Tennessee Technological Univ., School of Agriculture, Box 5034, Cookeville, TN 38505.

${ }^{2}$ Professor.

Abbreviations: $\mathrm{ABA}$, abscisic acid: $\mathrm{CH}$, hours of chilling; FC, forcing conditions; RRP, roof regeneration potential.
(DeWald and Feret, 1987; Farmer, 1975; Lathrop and Mecklenburg, 1971; Webb, 1977). Enhancements in the magnitude, rate, and earliness of budbreak in response to chilling have also been demonstrated for several Malus spp. (Arnold and Young. 1990). It is unknown to what extent the enhancement of root growth in response to chilling depends on shoot growth enhancement by chilling and vice versa.

In apple, proteins in senescing leaves in the fall are transferred to storage sites in the bark (Kang and Titus, 1980b). Remobilization of these reserves often accompanies active growth of overwintering buds in the spring, but it does not depend on this growth (Tromp and Ovaa, 1971). A scheme for regulation of bark protein levels by seasonal variations in endogenous abscisic acid (ABA) concentration has been proposed (Mousdale, 1982, 1983a, 1983b; Mousdale et al., 1986). While information on shoot bark proteins is available (Kang and Titus, 1980a, 1980b; O'Kennedy and Titus, 1979), nothing is known about protein changes in the roots in response to chilling.

The objectives of this study were to: 1) determine if root and shoot growth respond similarly to chilling; 2) determine if changes in the magnitude, timing. and rate of RRP and shoot extension growth were similar to those found earlier for budbreak (Arnold and Young, 1990; 3) determine if the responses of roots and shoots IO chilling during forcing were independent of growth of the other portion of the plant; and 4) monitor changes in protein content during chilling and forcing in both roots and shoots.

While seedling material in an allogamous species, such as apple, is more genetically variable than clonal material, seedlings, rather than clonal rooted cuttings, were used so that no shoot tissue would be included with the roots. Previous work by Young and Werner (1985b) indicated that the shank portion of clonal rootstocks reacted statistically like shoot tissue rather than like root tissue. Thus, uniform (Table 1), naturally defoliated, 1-yearold bare-root seedlings from open-pollinated blocks of Malus x domestica 'Delicious' (Lawyer's Nursey, Plains, Mont.) were dug in early November after receiving $<200 \mathrm{CH}$. All seedlings were single stem whips (one well-formed terminal bud per seedling), and only vegetative buds were present. The seedlings' roots were surrounded by moist sphagnum peat. Each entire plant was loosely wrapped in a polyethylene sheet inside a waxed corrugated cardboard box and stored at $16 \pm 2 \mathrm{C}$ until placed in experimental conditions on 3 Jan. 1989. Seedlings were then placed in a $5 \pm 1 \mathrm{C}$ cold room, a temperature reported to be optimal for breaking rest in many plants (Fuchigami and Nee, 1987). After $0,600,1200$, or $1800 \mathrm{CH}$, five seedlings were harvested. These seedlings served as controls for all four FC treatments. After each $\mathrm{CH}$ treatment, 60 additional seedlings (15 per FC treatment) were planted in Turface medium (fritted clay, AMCOR Applied Industrial Materials, Deerfield, Ill.) in 2.5liter plastic containers and transferred to FC. FC consisted of all four combinations of 5 $\pm 1 \mathrm{C}$ and $20 \pm 1 \mathrm{C}$ root and shoot temperatures maintained by use of a forced-air system (Saltveit, 1982) in an insulated chamber inside a 5C cold room. Shoot temperatures were estimated from air temperatures adjacent to terminal buds, while root temperatures were estimated from medium temperatures adjacent to the midpoint of the main roots. Seedlings were planted so that root collars were even with the tops of the containers. Quilt batting was placed on top of the medium and strips of fiberglass insulation secured between the seedlings to separate the 5 and 20C treatments. Fourteenhour photoperiods were maintained using 40$\mathrm{W}$ incandescent bulbs, providing $\approx 20$ $\mu \mathrm{mol} \cdot \mathrm{s}^{-1} \cdot \mathrm{m}^{-2}$ PAR incident on terminal shoot tips. The light source was outside of the chamber so that the light passed through a 4-mm clear polyethylene sheet into the shoot chambers. Thus, radiant heating of shoots by the light source was negligible. Air samples taken $15 \mathrm{~min}$ after watering following 600 $\mathrm{CH}$ indicated $0.0486 \%$ and $0.0663 \% \mathrm{CO}_{2}$ and $21.3 \%$ and $21.0 \% \mathrm{O}_{2}$ for roots and shoots, respectively. These $\mathrm{O}_{2}$ and $\mathrm{CO}_{2}$ levels and the porosity of the similar medium (van Bavel et al., 1978) suggest that $\mathrm{O}_{2}$ levels were not limiting.

Following 7, 14, and 21 days under FC. five seedlings from each temperature regime were harvested. Shoot characteristics measured included: new and old total shoot length 
Table 1. Initial uniformity of Malus $\times$ domestica seedlings.

\begin{tabular}{|c|c|c|c|c|c|c|}
\hline \multirow{3}{*}{$\begin{array}{l}\text { Shooviroot } \\
\text { temperature } \\
\text { combination }\left({ }^{\circ} \mathrm{C}\right)\end{array}$} & \multirow{2}{*}{\multicolumn{3}{|c|}{ Old root fresh wt $(\mathrm{g})$}} & \multicolumn{2}{|c|}{ Old shoat } & \multirow[b]{3}{*}{ Buds'seedling (no. } \\
\hline & & & & \multirow{2}{*}{$\begin{array}{c}\text { Fresh wh } \\
\text { (g) }\end{array}$} & \multirow{2}{*}{$\begin{array}{l}\text { Length } \\
\text { (cm) }\end{array}$} & \\
\hline & Main & Lateral & Total & & & \\
\hline $5 / 5$ & $11.0=2.3^{x}$ & $2.1 \pm 1.1$ & $13.1 \pm 3.1$ & $8.0 \pm 2.2$ & $46.8 \pm 4.9$ & $31.5 \pm 3.8$ \\
\hline $5 / 20$ & $10.9=2.5^{x}$ & $2.1=1.2$ & $13.0 \pm 3.3$ & $8.2 \pm 2.1$ & $48.6 \pm 4.1$ & $31.7 \pm 3.9$ \\
\hline $20 / 5$ & $10.7 \pm 2.9^{x}$ & $2.0 \pm 1.1$ & $12.7 \pm 3.3$ & $7.9 \pm 1.8$ & $46.8=3.7$ & $32.0 \pm 3.3$ \\
\hline $20 / 20$ & $10.7 \pm 2.9 x$ & $2.0=1.1$ & $12.7 \pm 3.2$ & $8.3 \pm 1.9$ & $48.1 \pm 3.2$ & $.32 .2 \pm 3.9$ \\
\hline $5^{x}$ & $12.6 \pm 2.8^{y}$ & $2.4=1.1$ & $14.9=3.2$ & $8.9 \pm 2.1$ & $48.1 \pm 5.1$ & $33.2 \pm 4.8$ \\
\hline
\end{tabular}

${ }^{\mathrm{z}}$ Rows of means \pm standard deviations with 60 observations per mean.

${ }^{\mathrm{y}} \mathrm{ROW}$ of means \pm standard deviations with 20 observations per mean.

${ }^{\mathrm{x}}$ Chilling and no forcing.
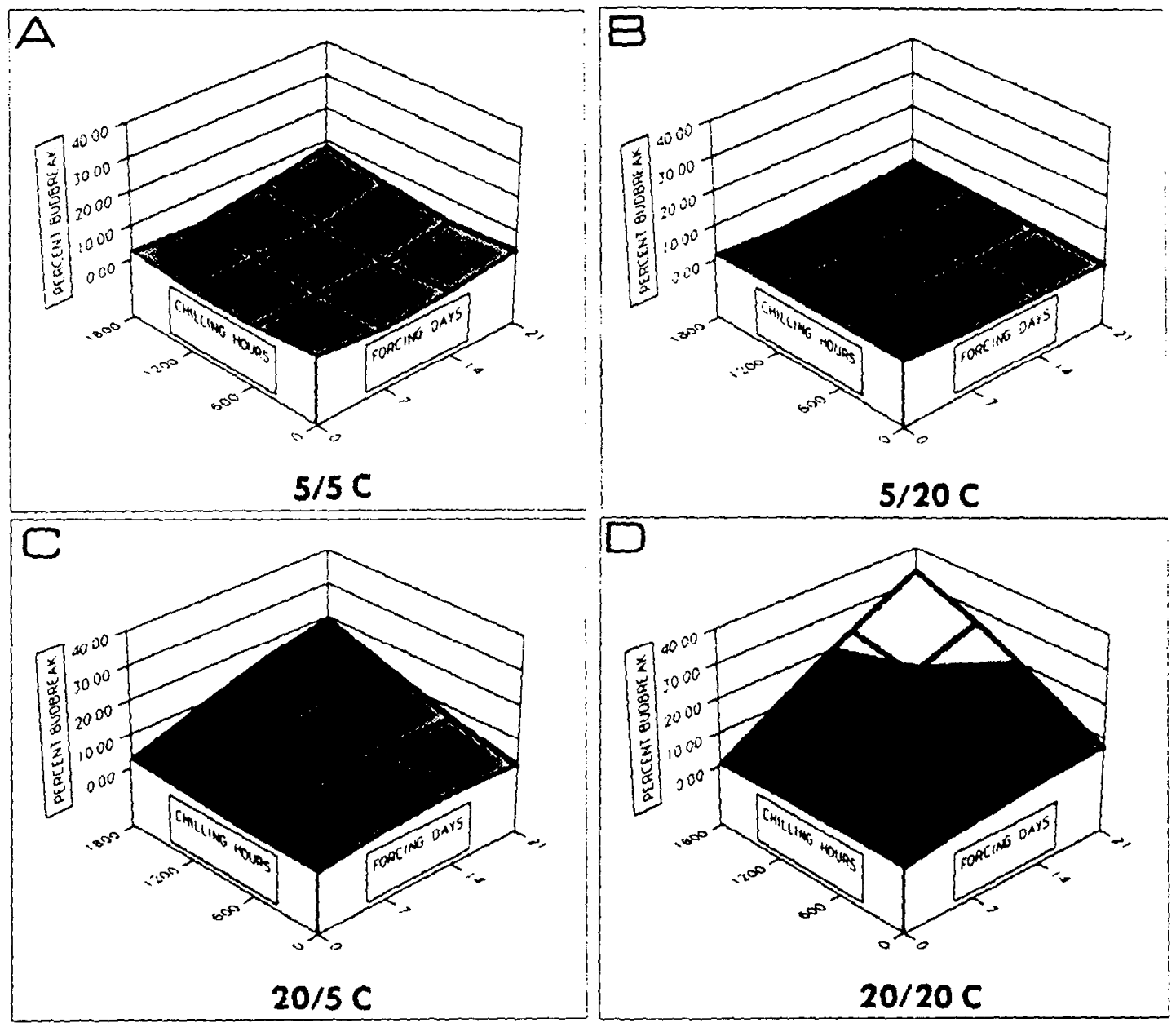

Fig. 1. Changes in budbreak in response to chilling at 5C. (A), (B), (C), and (D) are budbreak with 5/5. 5/20, 20/5, and 20/20C shoot/root FC, respectively. Shaded areas represent contours indicated on $\mathrm{z}$ axis. Full quadratic response surface equations are presented in Table 2.

and fresh weight, new shoot dry weight, total number of vegetative buds, number of buds broken (any green showing), and number of buds elongating $\geq 3 \mathrm{~mm}$. Measured root characteristics were old root fresh weight, new root fresh and dry weights, number and length of roots $\geq 0.6 \mathrm{~mm}$ in diameter (large roots), and number of roots $<0.6 \mathrm{~mm}$ in diameter (small roots). New root : shoot ratios, percent budbreak (number buds broken/ total number of buds), and percent of buds expanding $\geq 3 \mathrm{~mm}$ were calculated. Also, number and fresh and dry weights of root suckers (adventitious shoots formed on the roots) were measured. For all root and shoot growth criteria, dry weight measures responded similarly to fresh weight measures; hence, only fresh weights are presented.
The overall statistical design was a modified factorial with $4 \mathrm{CH} \times 4 \mathrm{FC} \times 4$ forcing times with five plant replications per each treatment combination except at 0 days of forcing. A restricted randomized design was used in which each forcing time occurred at least once in each row and column of each FC. Statistical analyses were performed using analysis of variance, polynomial regression, and full quadratic response surface modelling (Hicks, 1973; SAS, 1985).

Protein from $1 \mathrm{~g}$ fresh weight of old root and shoot bark samples from each seedling was extracted immediately after growth characteristics were measured. Extractions were done according to Menendez et al. (1986) with the following modifications: tissue was homogenized at a tissue : buffer ratio of 1:8 instead of 1:4, Triton X-100 was deleted from the buffer, as it resulted in high optical density readings for the buffer blank, and phenylmethyl sulfonyl fluoride was deleted as it did not improve extractions and is highly toxic to humans. Buffer components were obtained from Sigma Chemical Co. (St. Louis). Bark samples were taken from the middle of the 1-year-old shoots and tap roots. Bark consisted of all tissues from the vascular cambium outward, excluding overwintering buds. Protein concentrations were determined by the Bio-Rad protein assay (BioRad, Richmond, Calif.), a form of the Bradford assay (Bio-Rad, 1987; Bradford, 1976), using bovine serum albumin as the standard. The Bradford assay has been previously used to quantify apple bark proteins (Kang and 
Table 2. Full quadratic response surface equations and polynomial regression equations for Figs. 1 through 6 . In the following equations $\mathrm{CH}=$ number of hours of chilling at $5 \mathrm{C}$ and $\mathrm{FD}=$ days at forcing temperatures following chilling.

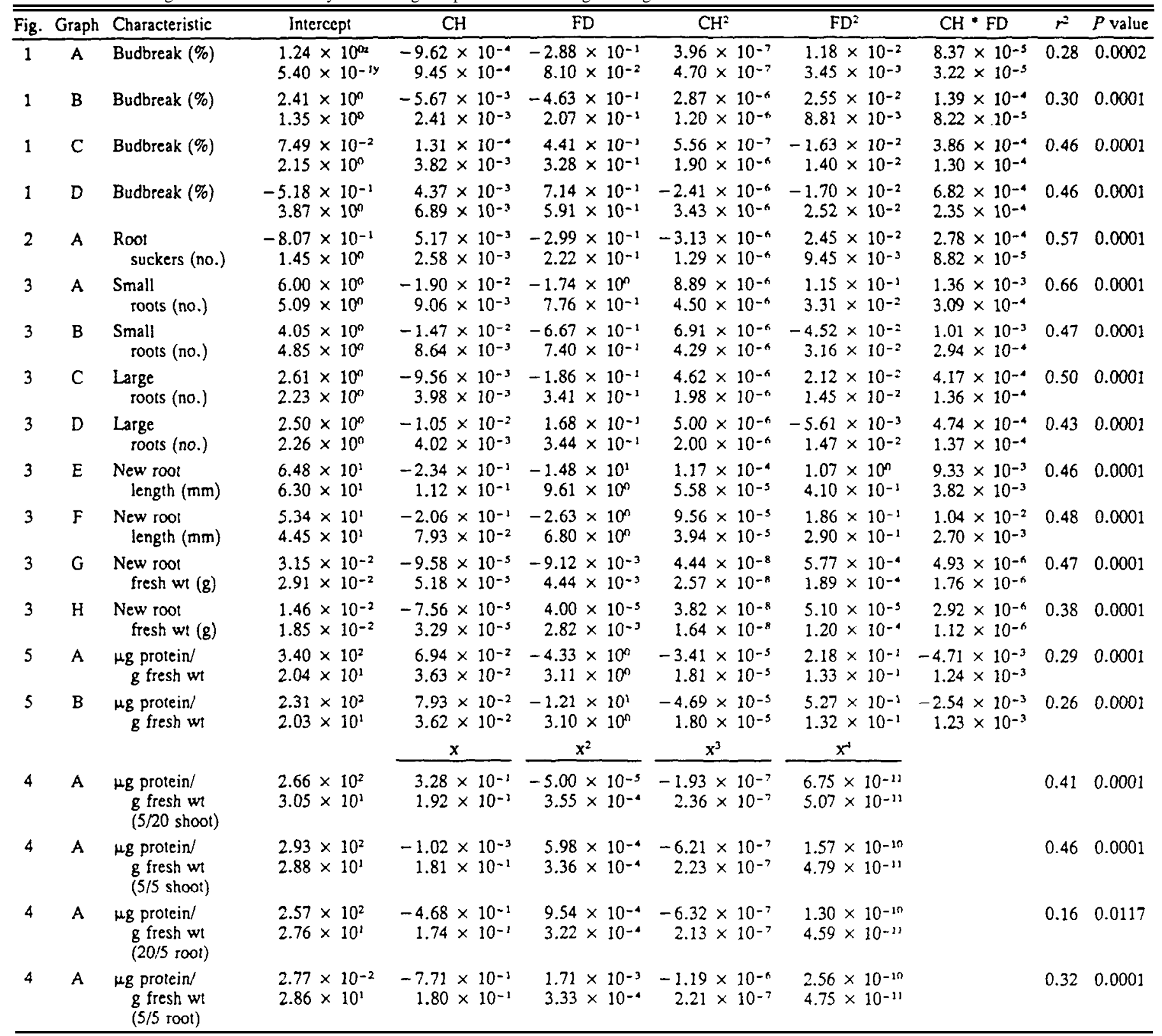

${ }^{\mathrm{z}}$ Coefficient.

${ }^{\mathrm{y}}$ Standard deviation of coefficient.

Titus, 1980a; Kang et al. 1982; Mousdale, 1982). While Kang and Titus (1980a) found that the Bradford assay yielded significantly lower values than did the Lowry procedure, they found that "a consistent quantitative relationship existed between the values obtained by the two procedures". Thus, while the Bradford assay may yield lower absolute protein levels than the Lowry procedure, it is a reliable assay for comparing $\mathrm{CH}, \mathrm{FC}$, and forcing time treatments. By combining the protein data from 0 forcing days at each $\mathrm{CH}$ treatment (i.e., 0, 600, 1200, and 1800 $\mathrm{CH}$ ) with the SC FC data (i.e., days 7, 14, and 21 of forcing) replication was increased and 16 sample times, rather than four, could be used to estimate protein changes during chilling. Also, protein changes could be estimated for 21 days $(\approx 500 \mathrm{hr})$, i.e., beyond

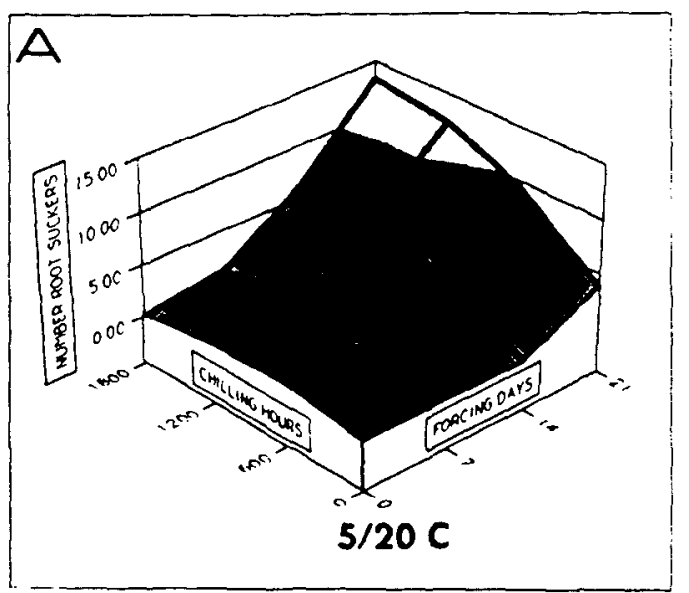

Fig. 2. Number of adventitious shoots (root suckers) formed on roots of seedlings with 5/20C FC. Shaded areas represent contours indicated on $\mathrm{z}$ axis. A full quadratic response surface equation is presented in Table 2. 

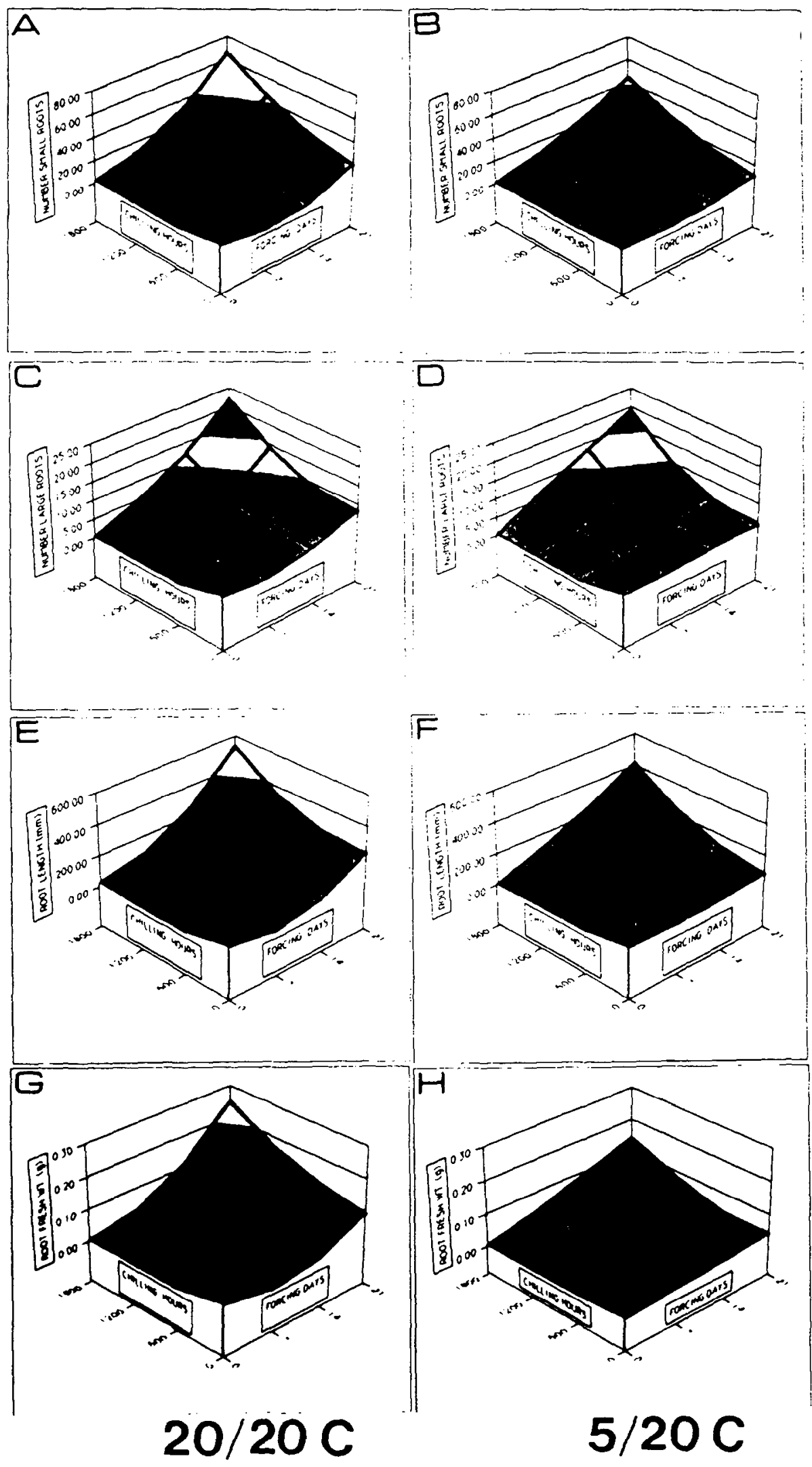

Fig. 3. Changes in root regeneration characteristics in response to chilling at 5C. Graphs (A), (C), (E), and $(\mathrm{G})$ depict numbers of small roots, number of large roots, total new root length, and new roof fresh weight, respectively. with both roots and shoots at 20C FC. Graphs (B), (D), (E), and (H) depict the same characteristics, respecrivcly, with 5C shoot and 20C root forcing conditions. Shaded areas represent contours indicated on $\mathrm{z}$ axis. Full quadratic response surface equations arc presented in Table 2. the $1800 \mathrm{CH}$ treatment to $2300 \mathrm{CH}$. With the exception of $0 \mathrm{CH}$ with 0 days of forcing (which was a reflection of protein status prior to chilling), protein levels appeared to be unaffected (other than by a continuation of the normal chilling processes) by potting the bare-root seedlings ( 0 days of forcing at 600 , 1200 , and $1800 \mathrm{CH}$ ) and placing them into 5C FC.

At the beginning of the experiment, an additional sample of 10 seedlings was harvested to determine the fresh weight proportion of root and shoot bark to total root and shoot weight, respectively. Total root and shoot bark protein per seedling was calculated by multiplying the above proportion ( 0.381 for roots and 0.362 for shoots) by the seedling's total root or shoot fresh weight and root or shoot protein concentration as determined in the Bio-Rad assay.

Near $0 \%$ budbreak occurred during forcing when shoots were at SC, regardless of root temperature (Fig. $1 \mathrm{~A}, \mathrm{~B}$; Table 2). Bark slippage at the cambial layer(s) occurred only under 20C FC. At 5C, shoots would have been considered to be in endo- and/or paradormancy (Lang et al., 1987) if the chilling requirement had not been satisfied. After the chilling requirement $(\approx 1200 \mathrm{CH}$; Arnold and Young, 1990) was satisfied, shoots held at SC were considered to be in ecodormancy (Lang et al., 1987). With whole plants under 20C forcing, increased $\mathrm{CH}$ increased the magnitude, earliness, and rate at which budbreak occurred (Fig. 1D). An increase along the $\mathrm{z}$ axis at a particular combination of $\mathrm{x}$ and $y$ value indicates an increase in the magnitude of the response. A change in the slope of the response surface indicates a change in the rate of the response. Changes along the $\mathrm{z}$ axis occurring closer to or farther away from the $\mathrm{x}$ and $\mathrm{y}$ origins indicate a change in the timing of the response, New shoot length and fresh weight responded similarly to budbreak with increased $\mathrm{CH}$ (data not shown). A similar response for budbreak has been reported for several species of Malus (Arnold, 1990; Arnold and Young, 1990). Cold roots during forcing reduced the magnitude and slightly slowed the budbreak response to chilling but did not alter the overall pattern of budbreak (Fig. 1C). This result suggests a need for new root growth so that the maximum budbreak and shoot extension responses to chilling can be achieved. This relationship may affect top growth of outplanted bare-root stock during spring when soil temperatures are low. There have been reports of rootstocks influencing the chilling requirement in apple (Couvillon et al., 1984) and influencing the onset of winter dormancy in Salix (Junttila, 1988).

Few root suckers grew when the entire plant was under 20C FC and none while roots were held at 5C (data not shown). However, when the shoots were maintained in a state of ecodormancy (5C) while the roots were in active growth conditions (20C), there was more than a 10 -fold increase in root sucker 


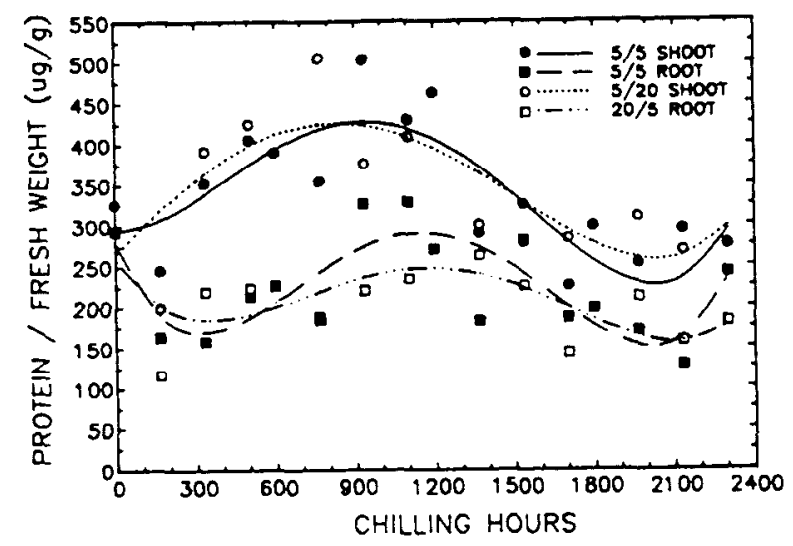

Fig. 4. Changes in bark protein concentration in response to chilling at 5C. Scatter plots of means (five observations per mean) and Polynomial regression lines generated from original observations. Shoots were in $5 / 20$ and $5 / 5 \mathrm{C}$ forcing conditions (5/20 shoot and 5/5 shoot, respectively) and roots in $20 / 5$ and $5 / 5 \mathrm{C}$ (20/5 root and 5/5 root, respectively) forcing conditions. Polynomial regression equations arc presented in Table 2.
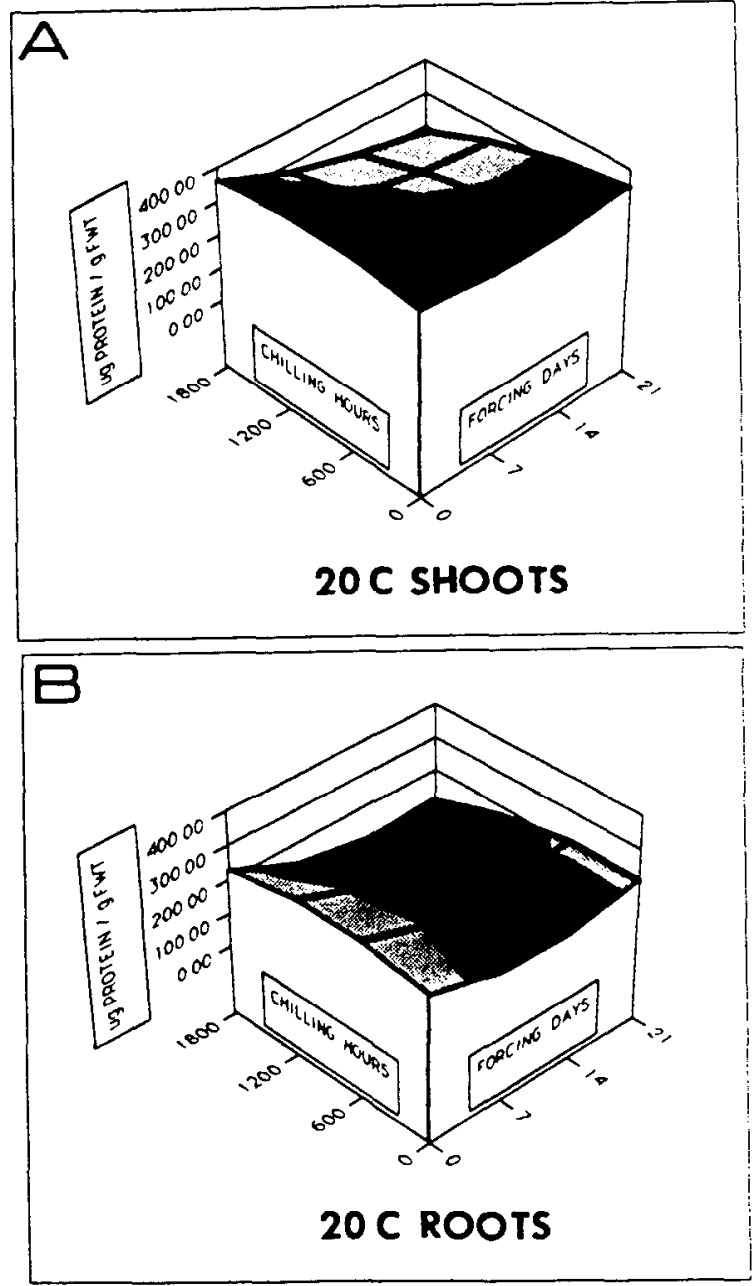

Fig. 5. Changes in protein concentration in rcponse to chilling at $5 \mathrm{C}$ followed by $20 \mathrm{C}$ forcing conditions. Shoot protein concentrations (A) for shoots under 20C forcing temperatures were averaged across root temperature treatments (5 and 20C). Likewisc, roots (B) were at 20C forcing temperatures with shoots at 5 or 20C. Shaded areas represent contours indicated on z axis. Full quadratic response surface equations presented in Table 2.

growth of fully chilled $(1800 \mathrm{CH})$ plants (Fig. 2; Table 2). Moreover, root sucker growth increased in magnitude, occurred earlier and at a faster rate with increased $\mathrm{CH}$ (Fig. 2). Root suckers originated primarily on lateral roots present at planting. Virtually no root tions in which the buds did not grow and roots were under conditions favoring growth, and since root sucker growth mimicked the response of shoot growth in favorable conditions, our results suggest that root sucker growth may be a response of the plant to maintain a root/shoot growth equilibrium. Maintenance of such an equilibrium has been demonstrated under numerous conditions (Brouwer, 1983; Lambers, 1983; Ledig and Perry, 1965; Reynolds and Thornley, 1982). Apple rootstocks differ in their propensity for root sucker growth in the field (Young and Unrath, 1982). However, it is unknown how or if these differences are related to differences in scion/rootstock chilling requirements.

When the entire plant was under $20 \mathrm{C}$ forcing, all measures of root growth increased in magnitude, occurred earlier and at a faster rate in response to increased $\mathrm{CH}$ (Fig. $3 \mathrm{~A}$, C, E, G; Table 2). This result confirms increases in the magnitude of root growth in response to chilling that were reported for several species of Malus (Arnold, 1990; Arnold and Young, 1990; Young and Werner, 1984, 1985b) and documents changes in the timing and rate of the response. The greatest differences in chilling enhancement of root growth between 5/20 and 20/20C shoot/root FC were expressed in the new root fresh weights (Fig. $3 \mathrm{H}, \mathrm{G}$, respectively). New root dry weight responded similarly (data not shown). Holding shoot buds in ecodormancy (SC) while roots were under growth conditions (20C) did not alter the overall pattern of enhanced root growth with increased $\mathrm{CH}$ and forcing days; however, it did reduce the magnitude and slightly slow the response (Fig. 3 ; Table 2). Hence, while root growth enhancement by chilling was augmented by active bud growth. a similar response was induced while the buds were maintained in a state of ecodormancy (comparison of Figs. $1,3)$. This study was not able to completely separate the effects of active shoot growth on root growth due to the prolific root sucker growth when the shoot buds were held at SC during forcing (Figs. 1B, 2).

Protein concentrations in shoot bark (Fig. 4; Table 2) tended to increase during chilling until shortly before ( 800 to $1100 \mathrm{CH}$ ) the reported chilling requirement for vegetative budbreak was satisfied, at $\approx 1200 \mathrm{CH}$ (Arnold and Young, 1990; Young and Werner, 1985a). Protein concentrations then sharply declined, remaining at lower levels through $2300 \mathrm{CH}$ (Fig. 4), suggesting a possible mobilization of protein reserves. We do not know why root protein concentrations and total root protein per seedling initially declined. Perhaps the protein concentration present during the first few hundred $\mathrm{CH}$ is more a function of prechilling conditions than chilling treatments. After an initial decline in protein concentration during the first 200 to $300 \mathrm{CH}$, root protein concentrations exhibited a similar although slightly delayed response to chilling. Similar patterns of protein accumulation followed by mobilization of those reserves have been reported in shoot bark of apple (Mousdale, 1983b; Mousdale et al., 
1986; Tromp and Ovaa, 1971) and Morus alba (Suzuki, 1984). In apple, the mobilization of protein reserves has been shown not to depend strongly on the demand for $\mathrm{N}$ by the bud (Tromp and Ovaa, 1971). We do not know why the decline in protein concentrations in the roots lagged slightly behind those in the shoots. Perhaps there are differences in the optimal chilling temperature between roots and shoots or in the total chilling units required. Numerous differences in optimal chilling temperatures have been reported among species (Fuchigami and Nee, 1987; Saure, 1985) as well as differences in total chilling units required by different bud types on the same plant (Latimer and Robitaille, 1981; Saure, 1985). While root bark protein concentrations were generally lower than those in the shoot bark, on a total protein-per-seedling basis, root and shoot systems contained similar amounts of protein after about the first $200 \mathrm{CH}$ (data not shown), possibly because of either larger amounts of total root than shoot tissue $(13.4$ vs. $8.3 \mathrm{~g})$ and/or because bark constituted a larger percentage of total tissue in the root than shoot (38.1\% vs. $36.2 \%$ on fresh-weight basis). Maintaining the root or shoot system at 5 or 20C had little effect on protein concentration or total protein in the other portion of the plant (Fig. 4). Tromp and Ovaa (1971) found that growth of expanding buds was supported from protein reserves just below the bud. This is consistent with our results in that changes in protein concentration in one portion of the plant appeared to have little effect on growth of the other plant parts.

In general, increased $\mathrm{CH}$ at $5 \mathrm{C}$ and increased days of forcing at $20 \mathrm{C}$ resulted in lower concentrations of protein in both roots and shoots (Fig. 5; Table 2). Lower concentrations of protein reserves with increased chilling were reported in apple shoot bark (Mousdale, 1982). Presumably, these bark proteins were supporting the increased growth of roots and shoots with increased $\mathrm{CH}$.

Overall. shoot, root, and root sucker growth measurements increased in magnitude, occurred earlier and at a faster rate with increased $\mathrm{CH}$. Growth patterns in root and shoot systems were similar, but were reduced in magnitude and slightly delayed when the other portion of the plant was in ecodormancy. Thus, root and shoot system responses to chilling were influenced by growth of buds or new roots, respectively, but a portion of the response to chilling appears to be inherent to both the root and shoot system. Mobilization of protein reserves may fuel the increased growth in response to increased $\mathrm{CH}$. Further research is needed to separate root sucker growth from the root growth response to chilling. A scheme for regulation of bark protein levels by seasonal variations in endogenous ABA concentration was proposed by Mousdale (1982, 1983a); changes in root protein content, as well as those in shoots, in this study were consistent with his findings, suggesting that follow-up studies on ABA changes in the root system with chilling may be beneficial.

\section{Literature Cited}

Arnold, M.A. 1990. Chilling enhancement of new root growth in species of Molar. PhD Diss., North Carolina State Univ., Raleigh.

Arnold. M.X. and E. Young. 1990. Differential growth responses of apple species to chilling and root pruning. J. Amer. Soc. Hort. Sci: 115: 196-202.

Bio-Rad. 1987. Bio-Rad protein assay. Bul. 1069, Bio-Rad Laboratories, 'Richmond,-Calif.

Bradford. M. 1976. A rapid and sensitive method for the quantitation of microgram quantities of protein utilizing the principles of protein dye binding. Anal. Biochem. 72:248-254.

Brouwer, R. 1983. Functional equilibrium: sense or nonsense? Neth. J. Agr. Sci. 31:335-348.

Couvillon, G.A.. N. Finardi. M. Magnani. and C. Freire. 1984. Rootstock influencei the chilling requirement of 'Rome Beauty' apple in Brazil. HortScience 19:255-256.

DeWald, L.E. and P.P. Feret. 1987. Changes in loblolly pine root growth potential from September to April. Can. J. For. Res. 17:635-643.

Farmer, R.E., Jr. 1975. Dormancy and root regeneration of northern red oak. Can. J. For. Res. 5:176-185.

Fuchigami, L.H. and C.C. Nee. 1987. Degree growth stage model and rest-breaking mechanisms in temperature woody perennials. HortScience 22:836-845.

Hicks. C.R. 1973. Fundamental concepts in the design of experiments. 2nd ed. Holt Rinehart, Winston, N.Y. p. 349.

Junttila, O. 1988. Effect of rootstock on photoperiodic control of elongation growth in grafted ecotypes of Salix. Physiol. Plant. 74:39-44.

Kang, S.-M. and J.S. Titus. 1980a. Isolation and partial characterization of an acid endoprotease present in dormant apple shoot bark. Plant Physiol. 66:984-989.

Kang, S.-M. and J.S. Titus. 1980b. Qualitative and quantitative changes in nitrogenous compounds in senescing leaf and bark tissues of the apple. Physiol. Plant. 50:285-290.

Kang, S.-M., K.-C. Ko, and J.S. Titus. 1982 Mobilization and metabolism of protein and soluble nitrogen during spring growth of apple trees. J. Amer. Soc. Hort. Sci. 107:209-213.

Lambers. H. 1983. 'The functional equilibrium', nibbling on the edges of a paradigm. Neth. J. Agr. Sci. 31:305-311.

Lang, G.A., J.D. Early, G.C. Martin, and R.L. Darnell. 1987. Endo-, para-. and ecodormancy: physiological terminology and classification for dormancy research. HortScience 22:371-377.

Lathrop, J.K. and R.A. Mecklenburg. 1971. Root regeneration and root dormancy in Taxus spp. J. Amer. Soc. Hort. Sci. 96:111-114.

Latimer, J.G. and H.A. Robitaille. 1981. Sources of variability in apple shoot selection for bud rest determinations. J. Amer. Soc. Hort. Sci. 106:794-798.

Ledig, F.T. and T.O. Perry. 1965. Physiological genetics of the shoot-root ratio. Proc. Soc. Amer. For. 39-43.

Menendez. R.A.. F.E. Larsen, and R. Fritts, Jr. 1986. Protein and isozyme electrophoresis and isoelectric focusing for the characterization of apple clones. Scientia Hort. 29:211-220.

Mousdale, D.M. 1982. Endogenous abscisic acid and the regulation of protein metabolism in shoot bark of apple (Malus domestica Borkh.). Biochem. Physiol. Pflanzen 177:601-610.

Mousdale, D.M. 1983a. Endogenous abscisic acid and the regulation of proteolytic activities in shoot bark of apple. Biochem. Physiol. Pflanzen 178:373-379.

Mousdale, D.M. 1983b. Seasonal variation and metabolism of abscisic acid in shoot bark and lateral buds of apple. Biochem. Physiol. Pflanzen 178:503-510.

Mousdale, D.M.A., S.A. Mousdale. and M.J. Hennerty. 1986. Biochemistry of a plant dormancy process: prospects for chemical regulation. Biologia Plant. 289-16.

O'Kennedy, B.T. and J.S. Titus. 1979. Isolation and mobilization of storage proteins from apple shoot bark. Physiol. Plant. 45:419-424.

Reynolds, J.F. and J.H.M. Thornley. 1982. A shoot:roor partitioning model. Ann. Bot. 49:585597.

Saltveit, M.E., Jr. 1982. An inexpensive controlled-temperature chamber. HortScience 17:886-887.

SAS. 1985. SAS user's guide: Statistics. version 5 (ed.). SAS Institute, Inc., Gary, N.C.

Saure, M.C. 1985. Dormancy release in deciduous fruit trees. Hort. Rev. 7:239-300.

Suzuki, T. 1984. Total nitrogen and free amino acids in Morus alba stems from autumn through spring. Physiol. Plant. 60:473-478.

Tromp, J. and J.C. Ovaa. 1971. Spring mobilization of storage nitrogen in isolated shoot sections of apple. Physiol. Plant. 25:16-22.

van Bavcl, C.H.M.. R. Lascano, and D.R. Wilson. 1978. Water relations of fritted clay. Soil Sci. Soc. Amer. 42:657-659.

Webb, D.P. 1977. Root regeneration and bud dormancy of sugar maple, silver maple, and white ash seedlings: effects of chilling. For. Sci 23:474-483.

Young, E. and C.R. Unrath. 1982. Rootstocks and interstems for controlling apple free size in North Carolina. North Carolina Apple Production Manual. N.C. Agr. Ext. Serv. AG-292, 11-82-2M.

Young, E. and D.J. Werner. 1984. Effects of rootsrock and scion chilling during rest on resumption of growth in apple and peach. J. Amer. Soc. Hort. Sci. 109:548-551.

Young, E. and D.J. Werner. 1985a. Chill unit and growing degree hour requirements for vegetarive bud break in six apple rootstocks. J.. Amer. Soc. Hort. Sci. 110:411-413.

Young, E. and D.J. Werner. 1985b. Effects of shoot, root, and shank chilling during rest in apple and peach on growth resumption and carbohydrates. J. Amer. Soc. Hort. Sci. 110:769774. 